\title{
Aberystwyth University
}

\section{sanrsaos \\ ABERYSTWYTH \\ UNIVERSITY}

\section{Volcanic eruptions dry fogs and the european palaeoenvironmental record: Localised phenomena or Hemispheric impacts?}

Grattan, John; Pyatt, J. P.

\author{
Published in: \\ Global and Planetary Change
}

\section{Publication date:}

1999

Citation for published version (APA):

Grattan, J., \& Pyatt, J. P. (1999). Volcanic eruptions dry fogs and the european palaeoenvironmental record: Localised phenomena or Hemispheric impacts? Global and Planetary Change, 173-179.

http://hdl.handle.net/2160/226

\section{General rights}

Copyright and moral rights for the publications made accessible in the Aberystwyth Research Portal (the Institutional Repository) are retained by the authors and/or other copyright owners and it is a condition of accessing publications that users recognise and abide by the legal requirements associated with these rights. research.

- Users may download and print one copy of any publication from the Aberystwyth Research Portal for the purpose of private study or

- You may not further distribute the material or use it for any profit-making activity or commercial gain

- You may freely distribute the URL identifying the publication in the Aberystwyth Research Portal

Take down policy

If you believe that this document breaches copyright please contact us providing details, and we will remove access to the work immediately and investigate your claim.

tel: +441970622400

email: is@aber.ac.uk 


\title{
Volcanic eruptions dry fogs and the European palaeoenvironmental record: localised phenomena or hemispheric impacts?
}

\author{
J.P. Grattan ${ }^{\text {a.) }}$, F.B. Pyatt ${ }^{b}$ \\ ${ }^{a}$ The Institute of Earth Studies, University of Wales, Aberystwyth, Dyfed. SY23 3DB, UK Environmental \\ Sciences Section, Department of Life Sciences, Nottingham Trent University, Nottingham NG11 8NS, UK
}

\begin{abstract}
This paper addresses the climatic and environmental significance of historical records of dry fogs, particularly from Mediterranean sources, which have previously been interpreted as indicating the occurrence of large scale volcanic eruptions. A consideration of material presented here suggests that such descriptions may not indicate the presence of stratospheric aerosols emitted in massive volcanic eruptions, which may be capable of affecting hemispheric climate for several years. Such descriptions may instead record the concentration of volcanic gases in the lower atmosphere from relatively minor, climatically ineffective but environmentally significant, volcanic eruptions. The 'mystery dust veil of AD 536' is discussed in the light of this debate and the need for caution when estimating the magnitude of a volcanic event from associated historical records is stressed. q 1999 Elsevier Science B.V. All rights reserved.
\end{abstract}

Keywords: dry fogs; volcanic eruption; mystery dust veil

\section{Introduction}

Historical records have been used both to enhance existing chronologies of volcanic events and to broaden our understanding of the environmental impact of such episodes. Research into the impact of volcanic eruptions upon the terrestrial environment has traditionally emphasised the role of the climatic forcing which may follow such events. However, recent research has begun to challenge these assumptions and instead draw attention to the direct impact of airfall tephra and toxic volatile gases and aerosols. These are emitted during eruptions and may be transported great distances from their source Grattan and Charman, 1994; Grattan and Pyatt, 1994 . Recent work by Baillie 1994. has drawn attention to the 'mystery dust veil of AD 536', which bears many of the hallmarks of being a volcanic stratospheric aerosol but which is not accompanied by corroborative evidence in either the Greenland or Antarctic ice-core acidity records. However, a detailed analysis of textual evidence suggests that not all such reported dry fogs and dust veils need indicate the formation of a stratospheric aerosol, and that many may in fact be confined largely to the near-surface layer of the lower atmosphere as a result of gas emissions in relatively minor eruptions. This has implications for the scale of volcanic events which may be extrapolated from reports of suchphenomena.

\section{The mystery cloud of AD 536}

The mystery cloud of AD 536 has been well documented Stothers and Rampino, 1983; Stothers, .1984, and attributed to the atmospheric effect of a massive, but unidentified, volcanic eruption. However, its volcanic provenance has been called into question by the lack of an associated peak in the ice-core acidity record ŽBaillie, 1994 . Nevertheless, contemporary descriptions of the event are unquestionably similar to others which are unequivocally accepted as describing volcanic events. "The sun became 
dim ... for nearly the whole year ... so that the fruits were killed at an unseasonable time” John Lydus, in Stothers and Rampino, 1983.

... the sun gave forth its light without brightness, like the moon, during this whole year, and it seemed exceedingly like the sun in eclipse, for the beams it shed were not clear, nor such as it is accustomed to shed Procopius, in Stothers and Rampino, 1983.

... the sun was dark and its darkness lasted for about 18 months; each day it shone for about 4 hours, and still this light was only a feeble shadow ... the fruits did not ripen and the wine tasted like sour grapes John of Ephesus, in Stothers, 1984 .

The above descriptions clearly document the veiling of the sun as seen by observers around the Mediterranean basin in AD 536, and are very similar to other ancient accounts attributed to volcanic activity. In $44 \mathrm{BC}$, Plutarch described a very similar phenomenon:

... during all that year, its orb wthe Sun $\mathrm{x}$ rose pale and without radiance, while the heat that came down from it was slight and ineffectual, so that the air in its circulation was dark and heavy owing to the feebleness of the warmth that penetrated it, and the fruits imperfect and half ripe, withered away and shrivelled up on account of the coldness of the atmosphere Plutarch, in Stothers and Rampino, 1983.

Both sets of descriptions, made over 500 years apart, are unquestionably similar. However, Plu-tarch's account has been linked to an ice-core acidity peak and attributed to the eruption of Etna in that year ŽHammer et al., 1980 ; given the similarity between the descriptions, the absence of corroborative evidence for a massive volcanic eruption in AD 536 is puzzling.

\section{The dry fog of 1783}

Comparison with two more recent historical observations, by Benjamin Franklin and Gilbert White, of a weakened sun in AD 1783, further suggest that the observations made in AD 536 were indeed the result of a volcanic eruption despite the absence of an ice-core acidity signal.

\subsection{Benjamin Franklin}

During several of the summer months of the year 1783 . . . there existed a constant fog over all Europe and great part of North America. This fog was of a permanent nature; it was dry, and the rays of the sun seemed to have little effect towards dissipating it ... They were indeed rendered so faint in passing through it that when collected in the focus of a burning glass, they would scarce kindle brown paper Franklin, 1784 .

\subsection{Gilbert White}

The summer of 1783 was an amazing and portentous one, and full of horrible phenomena ... the peculiar haze or smokey fog, that prevailed for many weeks in this island and in every part of Europe, . . . was a most extraordinary appearance, ... By my journal, I find that I had noticed this strange occurrence from June 23 to July 20 inclusive, during which period the wind varied to every quarter without making any alteration in the air. The sun, at noon, looked as blank as a clouded moon ... ŽWhite, 1789 . 


\subsection{Environmental impacts}

Many aspects of Franklin's and White's description are similar to the observations made in AD 536 and point to the presence of volcanic gases and aerosols in the atmosphere. However, the assumption that the sun was being obscured by aerosols in the stratosphere can be questioned by a study of many other contemporary observations made in 1783. White noted the occurrence of the fog from June 23 to July 20 and between these dates there are many accounts from across Europe which document damage to vegetation by volcanic gases and aerosols and reduced visibility at ground level. The following selection is typical:

The aristæ of the barley, which was coming into ear, became brown and weathered at their extremities, as did the leaves of the oats; the rye had the appearance of being mildewed; so that the farmers were alarmed for those crops ... The Larch, Weymouth Pine, and hardy Scotch fir, had the tips of their leaves withered; ... The leaves of some ashes very much sheltered in my garden suffered greatly ... All these vegetables appeared exactly as if a fire had been lighted near them, that had shrivelled and discoloured their leaves Cullum, 1786 .

On Wednesday June 25th . . . all the different species of grain, viz., wheat, barley, and oats, were very yellow, and in general to have had all their leaves ... withered, within 2 or 3 in. at their ends; the forward barley and the oats most so ... The sun was scarce visible even at mid-day, and then entirely shorn of its beams so as to be viewed by the naked eye without pain The Ipswich Journal, July 12, 1783.

So long in a country not subject to fogs, we have been covered with one of the thickest I remember. We never see the sun but shorn of his beams, the trees are scarce discernible at a mile's distance William Cowper, in King and Ryskamp, 1981 .

The oldest men upon the coast scarce remember any fog of so long continuance as the present, not being capable to descry the opposite shore for almost 3 weeks Whitehall Evening Post, July 15,

1783.

On the 24th, the fog was very dense and accompanied by a very strong smell of sulphur, especially in the morning although it was still noticeable in the afternoon; it was noticeable not only because of the smell but also because of the taste ... After the 24th, many people in the open air experienced an uncomfortable pressure, headaches and experienced a difficulty breathing exactly like that encountered when the air is full of burning sulphur, asthmatics suffered to an even greater degree: ... the fog caused a great extermination of insects, particularly amongst leaf aphids. On the morning of the 25th, the land offered an aspect of severe desolation, the green colour of the plants had disappeared and everywhere the leaves were dry ... This affected a wide variety of plants: some were covered in spots, others changed gradually while some leaves dried up completely ... in a moment, the colour could change from green to brown, black, grey or white ... Afterwards, a great quantity of leaves fell Brugmans, 1787 .

The thick dry fog ... seems to have spread over the whole surface of Europe; . . . in the day time, it veils the sun and towards evening it has an infectious smell; in some places, it withers the leaves, and almost all the trees on the borders of the Ems have been stripped of theirs in one night The Ipswich Journal, August 9, 1783 .

A letter from Provence, July 11th. The fog sometimes emits a strong odour and is so dry it does not tarnish a looking glass and instead of liquefying salts it dries them The Aberdeen Journal, 
August 18, 1783 .

A letter from Paris, July 4th. For a considerable time past, the weather has been very remarkable here; a kind of hot fog obscures the atmosphere, and gives the sun much of that dull red appearance which wintry fogs sometimes produce. The fog is not peculiar to Paris, those who come lately from Rome say it is as thick and hot in Italy, and even the top of the Alps is covered with it, and travellers from Spain affirm the same of that kingdom General Evening Post, July 12, 1783 .

A letter from Naples, July 15, 1783. The fogs continue, and are accompanied with so alarming an increase of obscurity that our bargemen do not dare venture on the waters without compass The .Morning Herald and Advertiser, August 19, 1783 .

... This fog was nearly always dry and damaged the corn which yielded hardly any crop M.

Picard, Cure of Oinville, France, in Rabartin and '

... a a fog which arose at the beginning of June . . turned the sun to the colour of blood. This fog lasted until the last days of July and then returned at the end of August and continued well into September. It was thick, dry and had a sulphurous odour. We could see no break in this cloud for 300 paces ... This fog was nearly always dry and damaged the corn which yielded hardly any crop M. Picard, Cure of Oinville, France, in Rabartin and Rocher (1993)

Fig. 1. A simple model of the transport pathways of volcanic material from Iceland to Europe in June 1783. 


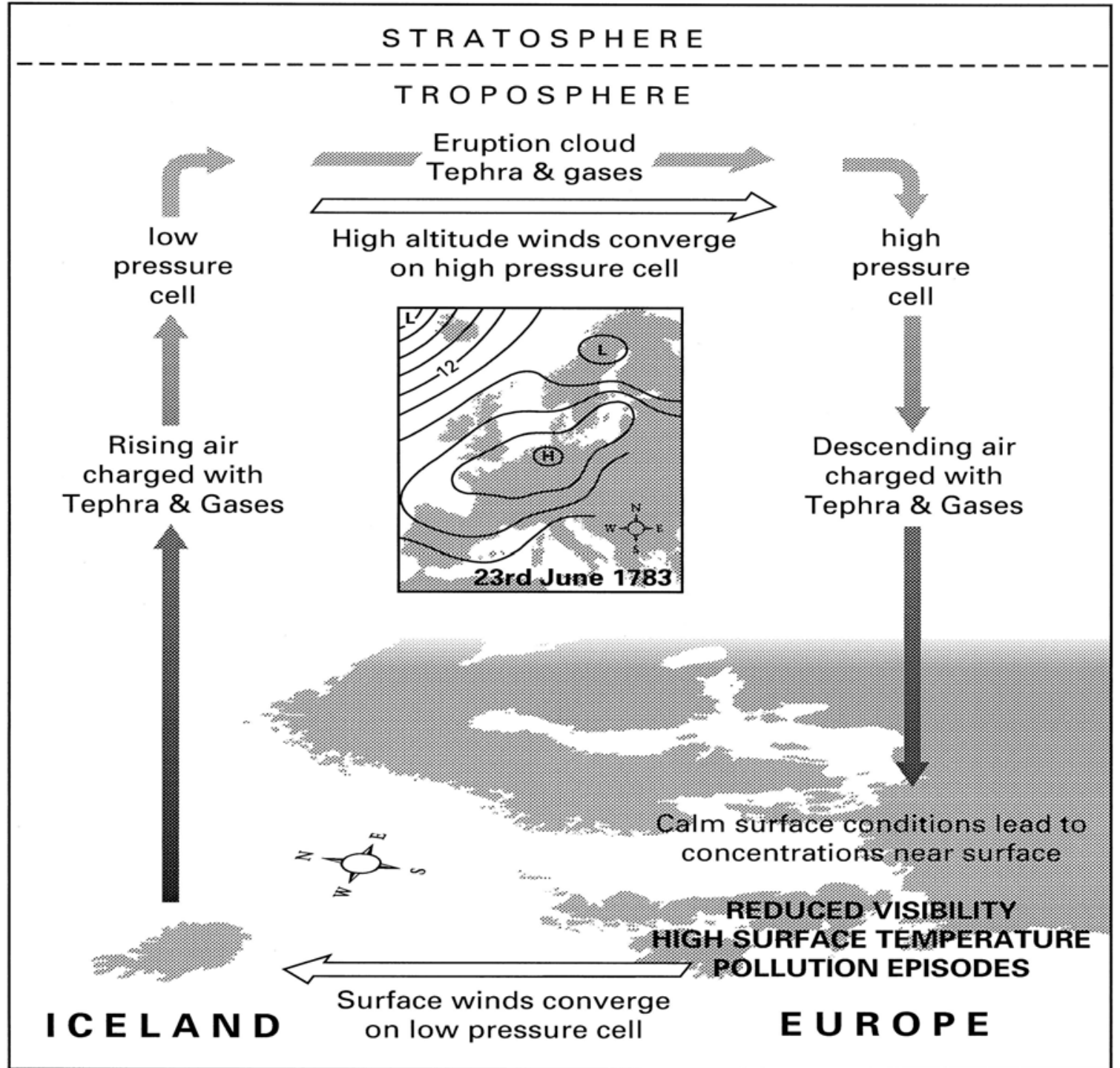

Synoptic map adapted from Kington Ž1988 .

Reports of crop damage, sulphurous smells, re-returned at the end of August and continued well are common in these reports from across Europe and it is reasonable to suggest that all these phenomena are caused by the same factor, a concentration of volcanic gases and aerosols in the lower atmosphere. Descriptions of an obscured sun and poor crops need not therefore be taken to indicate the presence of volcanic material in the stratosphere; on the contrary all the available evidence in 1783 points to a concentration of volcanic gases and derived aerosols in the lower atmosphere. This has obvious implications for the scale of volcanic event which is thought necessary to generate the phenomena described since it does not require a major volcanic event to inject material into the troposphere Garrec et al., 1977; Allard et al., 1991 . The scale and impact of the dry fog and pollution event in 1783 is important. The documentary record does not detail damage to crops on an hemispheric scale, or drastic changes to hemispheric climate, but does document locally intense dry fogs and crop damage which many observers found alarming Grattan and Brayshay, 1995. The available meteorological data ŽKington, 1988 .indicates that the phenomena described above, in 1783, were the result of the concentration of volcanic gases near the Earth's surface by stable anti-cyclonic air over Europe Fig. 1 , and were therefore confined to a limited geographical area and restricted temporally by the presence of specific meteorological conditions which were independent of volcanic activity.

The descriptions above are of course associated with the eruption of the Laki Fissure and the emission of $9.9=10^{13}$ g of acid Palais and Sigurdsson, 1989; Thordarson and Self, 1993 , but remarkably similar descriptions have now been documented in the Italian historical record and which are frequently associated with the orders of magnitude smaller eruptions of Italian volcanoes Camuffo and Enzi,1995 . 


\section{Dry fogs in the Italian historical record}

Camuffo and Enzi 1995. have documented many references in Italian historical material to DRY FOGS. These were malodorous fogs which damaged vegetation, did not wet surfaces, caused a weak sun, red dusks and lunar halos, all being classic descriptions of the presence of volcanic aerosols in the atmosphere and very similar to the phenomena described in $\mathrm{AD}$ 536. Cattle are recorded as dying after eating pasture or fodder contaminated by these fogs and epidemics and respiratory disease in Humans is also described. By their similarity to well documented events described above these fogs appear to be volcanic in origin and to be capable of travelling $10^{3} \mathrm{~km}$ from source. In the Eighteenth and Nineteenth centuries Dry Fogs were so common in Italy that they justified a section in agricultural textbooks:

among the different species of fogs we can, for agricultural purposes reduce them to two only. The damp fogs and the dry fogs. The damp fogs favour agriculture. The dry fogs, form a haze through which the sun appears to be a bright red ... if such fogs occur at a time near their maturity; then the grain can be seen to be yellow, ... becomes flaccid, and sometimes empties completely Fiandrini, in Camuffo and Enzi, 1995 .

Camuffo and Enzi note the occurrence of dry fogs in 1374, 1499, 1587, 1592, 1648, 1682, 1689, 1710, 1735, 1767, 1775, 1780, 1783, 1785, 1786, 1791, 1794, 1802, 1803, 1805, 1812, 1814, 1816, 1819, 1821, and 1869. As in 1783, the associated descriptions suggest an acid fog concentrated near the ground surface. In 1499, 'A fog in Orvieto burned the grain'. In 1592, 'A fog dried the grains'. In 1648, during the evening of June 23: fog 'fetid and rank' ruined the harvests causing famine in Romagna. In 1663, 'all of a sudden there was a fog that caused incredible damage in the whole of the Romagna, ... and therefore the harvest was very poor'. In 1710, fog damaged the harvest in Lombardy and the Piedmont. In 1775 in Padua, 'corrosive fog damaged the wheat' and 'fog damaged the maize in Veneto'. In 1780 , 'the fog was seen to spread slowly through the seeded fields, ... It was estimated that a quarter of the harvest was destroyed in the Polesine'.

The occurrence of many dry fogs is linked by Camuffo and Enzi to the eruption of Italian volcanoes in the early summer, a stable high pressure air mass over the volcanoes and a cold sea, very similar to the conditions which led to the pollution episode in 1783. In the context of the 'Mystery Cloud of AD 536' and the absence of any associated ice core acidity signal, it is worth noting that the majority of the acid fogs listed above are not associated with a significant acidity signal in either the Arctic or Antarctic ice-core acidity records.

\section{Discussion}

The historical records of dry fogs and diminished sunlight need not be recording the incidence of stratospheric aerosol clouds and hence the occurrence of major volcanic eruptions. Such records may instead be reporting the presence of dry acid fog in the lower atmosphere from relatively minor volcanic events, which need not be associated with ice-core acidity levels above the background noise in the cores. Such volcanic events cannot cause climate change and hence an environmental response on an hemispheric scale, but are nonetheless capable of causing locally intense environmental change, particularly when the gases and aerosols are concentrated by meteorological conditions.

The frequency of dry fogs in the recent Italian historical record is also worth noting. Dry fogs and crop damage were recorded in 4 years of the 1780s, and between 1775 and 1805, dry fogs were recorded in 10 different years. Volcanic forcing of the environment by local concentrations of aerosols may therefore be far more frequent than might otherwise be suggested by a consideration of years with major acid peaks in the ice-core record.

Dry fogs are actually very common in the Italian record. The majority of these do not indicate major volcanic eruptions capable of initiating hemispheric climatic change but eruptive, or perhaps non-eruptive degassing concentrated by regional air circulation. The 'Mystery Cloud of AD 536' is therefore more easily understood as an acid fog confined to the troposphere than as a stratospheric aerosol cloud. 
This review has demonstrated that the direct impact of volcanic gases and aerosols, concentrated near the Earth's surface is a potent mechanism for environmental change and that such phenomena need not be associated solely with massive volcanic eruptions which leave a clear signal in the ice-core acidity record. Far more documentary material undoubtedly exists to lay alongside the models constructed from palaeoenvironmental research, but the material presented here certainly demonstrates that volcanic forcing of the environment via acid deposition may have been more common than hitherto considered and that an intense environmental response may be generated at great distances from relatively minor volcanic events.

\section{References}

Allard, P., Carbonelle, J., Dajlevic, D., Le Bronec, J., Morel, P., Robe, M.C., Maurenas, J.M., Faivre-Pierret, R., Martin, D., Sabroux, J.C., Zettwoog, P., 1991. Eruptive and diffuse emissions of CO2 from Mt. Etna. Nature 351, 387-391.

Baillie, M.G.L., 1994. Dendrochronology raises questions about the nature of the AD 536 dust-veil event. The Holocene 4 Ž.2 , $212-$ 218.

Brugmans, S.J., 1787. Natuurkundige verhandeling over een zwavelagtigen nevel den 24 Juni 1783 innde provincie van stad en lande en naburige landen waargenomen. ŽA physical treatise on a sulphuric smog as observed on the 24 th of July 1783 in the province of Groningen and neighbouring countries , Leyden, 58 pp.

Camuffo, D., Enzi, S., 1995. Impact of the clouds of volcanic aerosols in Italy during the last 7 centuries. Natural Hazards 11, 135161.

Cullum, S.J., 1786. Of a remarkable frost on the 23rd of June, 1783. Philosophical Transactions of the Royal Society Abridged volume Ž.15, 604.

Franklin, B., 1784. Meteorological imaginations and conjectures. Mem. Lit. Philos. Soc. Manchester 2, 373-377.

Garrec, J.P., Lounowski, A., Plebin, R., 1977. The influence of volcanic fluoride emissions on the surrounding vegetation. Fluoride 10, 153-156.

Grattan, J.P., Brayshay, M.B., 1995. An amazing and portentous summer: environmental and social responses in Britain to the 1783 eruption of an Iceland Volcano. The Geographical Journal 161 Ž.2 , 125-134.

Grattan, J.P., Charman, D.J., 1994. The palaeoenvironmental implications of documentary evidence for impacts of volcanic volatiles in western Europe, 1783. The Holocene 4 Ž.1 , 101- 106.

Grattan, J.P., Pyatt, F.B., 1994. Acid damage in Europe caused by the Laki Fissure eruption-a historical review. The Science of the Total Environment 151, 241-247.

Hammer, C.U., Clausen, H.B., Dansgaard, W., 1980. Greenland ice sheet evidence of post glacial volcanism and its climatic impact. Nature 288, 230-235.

King, J., Ryskamp, C., 1981. In: The Letters and Prose Writings of WILLIAM COWPER II Clarendon Press, Oxford.

Kington, J.A., 1988. The Weather for the 1780s over Europe. CUP, Cambridge.

Palais, J.M., Sigurdsson, H., 1989. Petrologic evidence of volatile emissions from major historic and pre-historic volcanic eruptions. In: Berger, A., Dickinson, R.E., Kidson, J.W. ŽEds. , Understanding Climate Change. Geophysical Monograph 52 mediterranean before A.D. 630 from written and archaeologcal7 , 31-53. sources. Journal of Geophysical Research 88 B8 , $6357-6371$.

Rabartin, R., Rocher, P., 1993. Les Volcans et la RevolutionWhite, G., 1789. The Natural History of Selbourne. Penguin, Francaise. L’Association Volcanologique Europeene, Paris. London.

Stothers, R.B., 1984. Mystery cloud of AD 536. Nature 307, Thordarson, Th., Self, S., 1993. The Laki ŽSkaftar Fires .and 344-345. Grımsvotn eruptions in 1783-1785. Bulletin Volcanologique Stothers, R.B., Rampino, M.R., 1983. Volcanic eruptions in the 55, 233 263. 